\title{
Herbals: The Connection Between Horticulture and Medicine
}

Jules Janick

Summary. The prehistoric discovery that certain plants cause harm and others have curative powers is the origin of the healing professions and its practitioners (priest, physician, and apothecary), as well as professions devoted to plants (botany and horticulture). The description of plants and their properties and virtues (termed herbals in the $16^{\text {th }}$ century) became an invaluable resource for the physician and apothecary. The earliest medicobotanical treatises date to antiquity. A Sumerian tablet from about 2100 вСе (before current era) contains a dozen prescriptions and proscribes plant sources. In China, the Pen T'Sao Ching, assumed to be authored by the legendary Emperor Shen Nung in 2700 вСЕ, but probably written in the first century, contains about 100 herbal remedies. The Ebers Papyrus, a medical treatise from ancient Egypt dates to 1550 все but contains material from 5-20 centuries earlier. In Greece, the great botanical treatise Enquiry into Plants of Theophrastus, devotes book IX to the medicinal value of herbs. The herbal De Materia Medica by Pedanios Dioscorides of Anazarba, a Roman army physician, written in the year 65, the most famous ever written, was slavishly referred to, copied, and commented on for 1500 years. The great epoch of printed herbals appeared in the $16^{\text {th }}$ century of which the most notable are Das Buch zu Distillieven (1500) by Hieronymus Brunschwig; Herbarum Vivae Eicones (1530, 1532, 1536) by Otto Brunfel; Kreüter Buch (1542) by Hieronymus Bock; De Historias Stirpium (1542) of Leonhart Fuchs; New Herball (1551, 1562, 1568) by William Turner; Commentarii “on Dioscorides” (1544) by Pier Andrea Mattioli; Crôÿdeboeck (1554) by Rembert Dodoens; and the Herball (1597) by John Gerard. Botany and medicine were essentially in step until the $17^{\text {th }}$ century when both arts turned scientific and, at this juncture, botanical works would essentially ignore medicinal uses while medical works were devoid of plant lore. Yet, the medicinal use of herbs continues as an alternate form of medicine and remains popular in various forms to the present day despite the questionable efficacy of many popular herbs and the reliance of many herbal recommendations on superstition and astrology. The fact that most drugs were originally plant-based has encouraged a new look at the medicinal properties of plants.

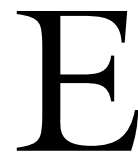

arly humans empirically determined the potential uses of the plants that surrounded them. Through trial and error they found plants that were agreeable or distasteful, edible or poisonous, that could cure or kill, could induce sleep, visions, or euphoria, and relieve symptoms of discomfort from constipation to anxiety. Plants with strong tastes and aromas (herbs and spices) were seized upon to alleviate illness and to enhance food. The prehistoric discovery that certain plants are edible or have curative powers and others are inedible or cause harm is the origin of the healing professions and its practitioners - priest, physician, and apothecary-and the plant sciences-botany and horticulture.

The early medical arts were associated with the search for and knowledge about healing substances as well as magic and religion. To understand the unknowable, humans created a panoply of gods, spirits, and forces, many of which were associated with or in the form of animals and plants which were and continue to be worshipped.

$\overline{\text { Department of Horticulture and Landscape Architecture, Purdue University, West Lafayette, IN 47907-1165. }}$ 
The cult of fertility, an almost universal belief of primitive humans, was symbolized by trees or animals and from this derives the Tree of Life, the Sacred Tree, the Cult of the Bull, and animal sacrifice. Knowledge of the healing power of plants became a special calling of the priest and magician, and this knowledge became a source of power. For thousands of years, the role of the priest and the physician were combined and exist today in the form of witch doctor, shaman, exorcist, and medicine man. The word pharmacy originated from an Egyptian term pharmaki and the Greek pharmakon and is related to another Egyptian word pharagia, which means the art of making magic.

In time, the healing profession diverged into separate professions, physician and priest, although there are many who wish to repair this dichotomy through wildly divergent means, from Mary Baker Eddy, founder of Christian Science, to Sigmund Freud, founder of psychoanalysis, and, most recently, various practitioners of alternate healing techniques known under the sobriquet of holistic medicine. The diversion of the medical profession from superstition and religion through a more systematic accumulation of knowledge, at first empirical and later experimental, has now made medicine truly a scientific discipline (Singer, 1958). The basis of the rational study of the medical arts was the insight that disease and sickness did not have a supernatural cause but a natural one. This concept is still not an obvious one and in many ways it is counter-intuitive; many still believe that sickness is due more to retribution than to natural causes. The priest, although clinging to the concept that religion controls the power of healing, has retreated from being a dispenser of cures, but many still maintain that the outcome of disease may still rely on the whim of the mind or on higher powers. Thus, miraculous cures, the power of relics, incantations, prayer, anointings, once the stock of the shaman, remain yet as a force in our religious beliefs, especially when the art of the physician proves feckless and impotent.

Through the course of medicine, from antiquity to the present, one of the chief sources of cures has been materials derived from plants. It is calculated that at the present time at least $70 \%$ of medicines are or were plant derived. Although plants are morphologically simple compared to animals, this sim- plicity of form has been compensated by a complex biochemistry, much of it to repel their own pathogens and predators. It is this ability of plants that is exploited by humans as medicines or as health functional phytochemicals. Thus, horticulture and the healing arts have long had a vital connection. This knowledge has been transmitted to us in books and treatises known as herbals, containing the names and description of plants with their properties and medical virtues (Singer, 1923, 1927). They have a long tradition in many cultures, ancient and modern. They represent the vital link between botany and medicine, horticulture and health. The history of herbals presented here draws heavily from four sources: Anderson (1977), Arber (1938), Blunt and Raphael (1979), and Singer (1958).

\section{Antiquity}

Ancient Cultures of the Near East, Far EASt, and Americas. Civilization occurred independently in various parts of the world including the TigrisEuphrates Valley, the Nile Valley, the Indus Valley, the Far East, and Central America. All developed an agriculture based on the cultivation of plants. The earliest civilization arose in Sumeria, an ancient culture of the Fertile Crescent (4500 вСE), which coalesced into the succeeding cultures of Akkadia, Babylonia, Assyria, and Judea. The Sumerians were non-Semitic people who settled in southern Mesopotamia, and developed the cites of Nippur, Lagash, Larsa, and Ur. They were the first to develop a system of writing using wedgeshaped or cuneiform impressions on clay tablets which date to before 3000 $\mathrm{BCE}$, the beginnings of written history. The Sumerians introduced the first systematic irrigated agriculture and refer to plant sources for healing prescriptions. The earliest known pharmaceutical compendium is a cuneiform tablet discovered at Nipur and dated at about 2100 $\mathrm{BCE}$ consisting of a set of formulas and directions for compounding (Fig. 1). Semitic people, Akkadians, settled to the north of Sumer. The legendary Sargon I, founder of the AkkadianSumerian Empire about 2500 BCE, discovered like Moses in a reed basket, became a gardener, and was rewarded with a kingship by the god Ishtar. Sumer and Akkad become the country of Babylonia. In the north, on both sides of the Tigris, the warlike Assyrians established themselves about 3000 BCE and developed the cites of Ashur and Ninevah. Early Babylonian-Assyrian medicine was largely dominated by the belief of signs and omens involving the priest as both diviner and exorcist yet including medical treatment. Examination of clay tablets in the library of King Assurbanipal of Assyria (668-626 BCE) identified 120 mineral drugs and 250 vegetable drugs including asafoetida, calamus, cannabis, castor, crocus, galbanum, glycyrrhiza, hellebore, mandragon, mentha, myrrh, opium, pine turpentine, styrax, and thymus. The medical information from Judea has come to us intact through the Hebrew and Christian bibles which are rich sources of information on herbs and spices.

Medicinal uses of plants are found in the ancient civilizations of the Indus Valley, Far East, and Central America (Rosengarten 1973). In Chinese legend, the Emperor Shen Nung, the Divine Cultivator and founder of Chinese medicine, authored the Pen T'sao Ching (The Classic Herbal) in 2700 BCE. This ancient herbal mentions more than 100 medicinal plants, including cassia, but was probably compiled in the first cen-

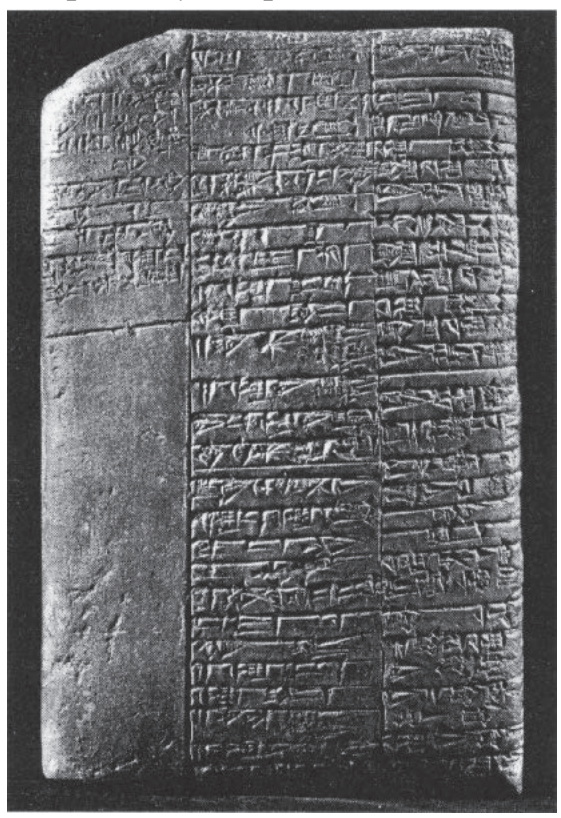

Fig. 1. A Sumerian cuneiform tablet discovered at Nipur and pressed into clay circa 2100 вCE is the earliest known medical text. The contents may be older, perhaps by as much as a millennium. One translation directs the practitioner to "pulverize the bark of pear (?) tree and the moon plant; infuse it with kushumma wine, let tree oil and hot cedar oil be spread over it" (Cowen and Helfand, 1988; Kramer, 1954). 


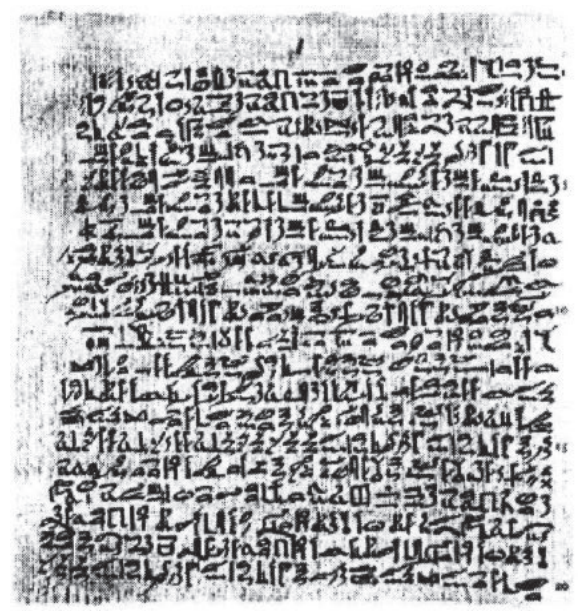

Fig. 2. The Ebers Papyms in Hieratic script, 1530 все. Source: Bryan (1936).

tury although it may contain information from centuries earlier. Cassia is mentioned by Confucius $(551-479$ BCE $)$ and in the Ch'u Ssu (Elegies of Ch'u) in the $4^{\text {th }}$ century BCE. The most comprehensive Chinese herbal, Pen Ts'ao Kang $M u$ compiled by Li Shih Cen, was first published in 1596.

Evidence of herbal use in India predates the $1^{\text {st }}$ millennium BCE with listings of plants for therapeutic value dating to 500 BCE. Medical writings of Charaka ( ${ }^{\text {st }}$ century BCE) and Susruta II ( $2^{\text {nd }}$ century) refer to medicinal herbs and spices. An Aztec herbal, compiled in 1522 by de la Cruz-Badiano, includes hallucinogenic plants such as peyote.

Ancient Egypt and the Ebers PAPYrus. Egypt has a continuous 6000year record with a unique and productive agriculture at its base (Janick, 2002). From 4000-3000 BCE people in the Nile Valley established highly advanced agricultural technology, formed a government, and as early as 3000 BCE constructed the first pyramids. There is a direct connection between medicine and plant lore in Ancient Egypt. A medical treatise looted from an XVIII dynasty tomb, and acquired by a German Professor, George Ebers in 1862 for the then enormous sum of $\$ 8000$, is perhaps the earliest known complete book of any kind. The Ebers Papyrus, dating to about $1550 \mathrm{BCE}$, is a collection of 811 prescriptions, interspersed with diagnosis, symptoms, physiological descriptions of the action of the heart, and concluding with the surgical treatment of wounds and sores (Bryan, 1936; Sonnedecker, 1976). The manuscript, an undamaged scroll over $30 \mathrm{~cm}$ wide $\times$ $20 \mathrm{~m}$ long, consists of over 3000 lines of text written in a cursive script called Hieratic (Fig. 2). The text, interspersed with spells and incantations, is a compilation and contains remnants of earlier material; one passage presumes to date from the first dynasty, about 3400 BCE.

Some of the recipes seem quite fantastic and are composed of a mixture of various substances including botanicals, animal and insect parts, and minerals. Were they efficacious? It seems unlikely that most of them were, but in several of them, it is quite clear that a therapeutic effect could be due to at least one of the ingredients. For example, there are a number of remedies to cure constipation involving castor oil while poppy was prescribed to induce sleep. Autumn crocus, the source of colchicine, is also prescribed in a diuretic medicine, but it is unclear if its use to relieve gout was known. Other plant materials used include acanthus, acacia, aloe, Arabian wood, balsam, barley, caraway, cedar, coriander, crocus, cucumber, cyperus, date, elderberry, favabean, fennel, fig, flax, garlic, grape, juniper, lettuce, linseed, mint, mulberry, nasturtium, onion, palm, papyrus, peppermint, pomegranate, poppy, saffron, sycomore fig, watermelon, wheat, willow, wormwood, and Zizyphus-lotus, Many of the recipes were complex and carefully proportioned. They were administered as gargles, snuffs, inhalations, fumigations, suppositories, enemas, poultices, decoctions, infusions, pills, troches, lotions, ointments, and planters.

Greece And Rome. Greek civilization, one of the foundations of Western Civilization, is the source of philosophy,

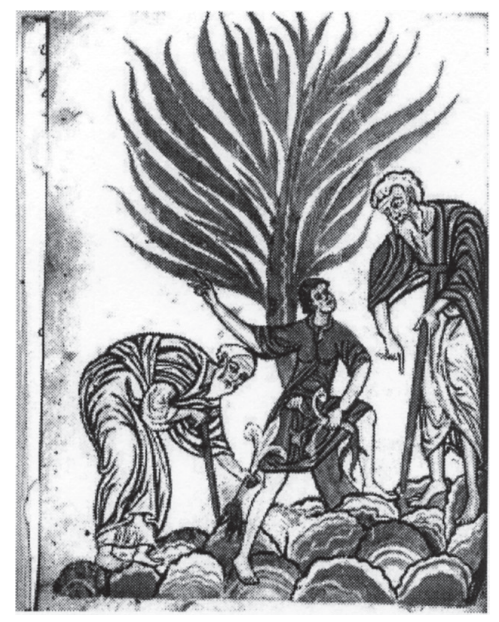

Fig. 3. Rhizotomists gathering herbs (Apuleius Platonicus herbal circa 1200). Source: Blunt and Raphael (1979). literally friend of wisdom. Greek philosophy involved a search for rational explanations of events in the natural world, including the healing arts. As in earlier civilizations, the healing arts in Greece trace to religious beliefs. In the $7^{\text {th }}$ century BCE, Asklepios aided by his two daughters, Hygeia and Panacea, superceded Apollo as the greatest of healing gods, and temples in his name were built to heal the sick. Legend has it that the centaur Chiron taught Asklepios pharmaceutical knowledge about drug plants.

Hippocrates (460-370 BCE), the developer of a Greek school of healing, was the first to expound the theory that diseases had natural rather than supernatural causes. Based on the color and pallor of ill people, disease was considered to be an imbalance of the four humors: blood, phlegm, yellow bile, and black bile, a concept that was to affect medicine for 2000 years. Healing emphasis was placed on purges in an attempt to purify the body from the illness producing excess of humors. The use of drugs was not ignored and between 200 and 400 herbs were known. Associated with the Hippocratic School, but predating it, was a group of experts of medicinal plants, rhizotomi (root diggers) who collected indigenous vegetable roots and sold them as pharmaceuticals (Fig. 3). The earliest known Greek herbal, written in the $3^{\text {rd }}$ century BCE by Diocles of Carystus, is no longer extant but a few fragments from an illustrated herbal of Krateuas survive from the lst century BCE.

Theophrastus' Historia de Plantes and De Causis Plantarum. Two botanical treatises of Theophrastus of Eresos, 372-287 BCE (Fig. 4), have survived in translations and represent the greatest source of botanical and horticultural information from antiquity.

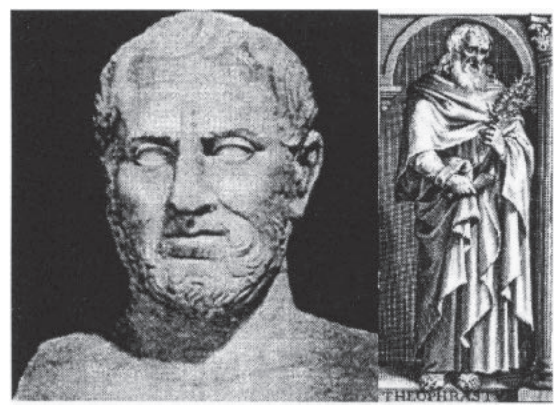

Fig. 4. Theophrastus of Eresos. Left: Portrait Roman bust (Janick, 1989). Right: Image from Gevarde's Herball, $2^{\text {nd }}$ ed. (1633). 

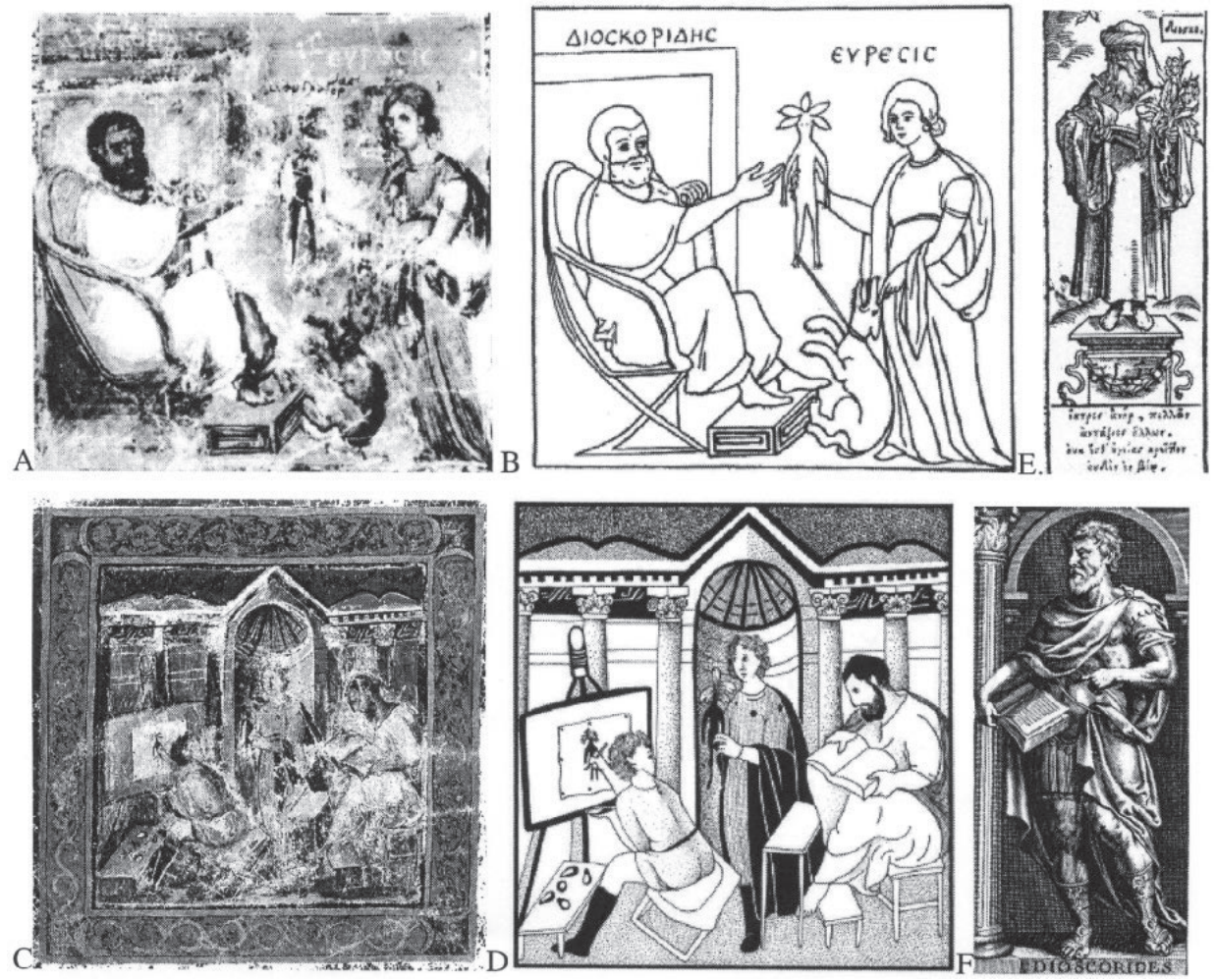

Fig. 5. Pedaniius Dioscorides (circa 20-70 CE). (A) Dioscorides receiving mandrake from the nymph Epinoia (Discovery) for Krateuas to paint. From Codex Vindobonensis, of Dioscorides' Materia Medica, about 512 CE. Source: Raphael (1979). (B) Scene in A traced by Singer (1958). (C) Epinoia shows the mandrake to Dioscorides (right) and Krateuas (left) in the Codex Vindobonensis. Source: Christopher (1981). (D) Scene in B drawn by Martha Breen (Bredemeyer). Source: D'Andrea (1982) (E) Dioscorides from title page of Brunfel's Herbarium Vivae Eicones, 1530. Source: Anderson (1977). (F) Dioscorides from title page of Gerarde's Herball (1633), $2^{\text {nd }}$ ed. Source: Johnson (1633)

Theophrastus of Eresos (372-287 BCE) was a student and successor of Aristotle as head of the Lyceum, a combination school, museum, and research center under the patrimony of Alexander. Aristotle's botanical works are lost but the two treatises, Historia de Plantes (Enquiry into Plants) and De Causis Plantarum (OfPlants, an Explanation) represent the culmination of a millennium of experience, observation, and science from Egypt and Mesopotamia. Although they contain pharmacological information, they are not herbals in the traditional sense but appear to be the equivalent of lectures containing empirical observations about the plant sciences, what we now consider plant morphology, classification, seed and vegetative propagation, geographic botany, forestry, horticulture, insect pests, and plant flavors and aromas. Book IX of the Enquiry discusses herbs as medicines, the kinds and parts of plants used, collection methods, and effects on humans and animals. It includes examples of valid techniques learned from empirical methods and observation, reports of others, as well as superstitious herbal practices. Although Theophrastus' work was lost to the West until the Renaissance, the manuscript fortunately survived in Syria and was later translated into Arabic, from which it was translated into Latin. An English translation of Theophrastus' botanical works is available in the Loeb Classical Library series, the last volume published in 1990.

Dıoscorides' De Materia Medica. Precious little is known about Pedaniius Dioscorides (Fig. 5), the Latinized name of Pedianos Dioskurides (20-70 вСE). $\mathrm{He}$ was born in Anazarba, a city in Northern Cilicia, in southeast Asia Minor (lesser Armenia), near Tarsus, in what is now Southeastern Turkey. He served in the Roman army, perhaps as a physician and traveled widely. His endearing fame rests on his only known work, a compilation concerning about 500 plants, written in Greek in the year 65, now known under its Latin title $D e$ Materia Medica. It contains good de- scriptions of plants giving their origins and medical virtues. The work was translated into Syriac and then translated into Arabic and Persian and became an important text in the Moslem world. In the West it was translated into Latin and in the Renaissance was translated with commentaries into Italian, German, French, Spanish, and Bohemian. Between 1652 and 1655 , the English botanist John Goodyer translated it into English, but this version remained unpublished until the $20^{\text {th }}$ century (Gunther, 1934).

Although the original manuscript appears not to have been illustrated, a magnificent copy (Codex Vindobonensis) with over 400 colored illustrations (Fig. 6) was made in 512 for Juliana Anicia, daughter of Flavius Anicius Olybrius, briefly Emperor of the West before his death in 472 and this manuscript may be the source of other copies. This manuscript passed through several hands where it was amended with plant names in Turkish, Arabic, and Hebrew, the latter no doubt penned by its last owner, the Jewish physician to Suleiman the Magnificant. In 1562 the ambassador to Turkey from the Holy Roman Emperor, Ogier Ghiselin de Busbecq (1522-1592), famous for the introduction of the horse chestnut, lilac, and tulip from the near East to Western Europe, noted the existence of the manuscript, but could not negotiate a price. It was eventually purchased, probably by the Emperor of the Holy Roman Empire, Maximilian II, and placed in the Imperial Library in Vienna and it is now the most valued possession of the Österreichische Nationalbibliothek. A facsimile edition was published in five volumes in 1965-1970.

Of the 500 plants in the text, about 130 were noted in Greek fragments (Hippocratic Collection) several centuries earlier. According to Singer (1927), 44 of the drugs mentioned by Dioscorides survived in the official pharmacopoeias of Europe up to the $20^{\text {th }}$ century. Despite the fact that there is precious little in the book that could be construed as efficacious, Disocorides work was to become the most influential herbal written, and remained the final authority on pharmacy for over 1,500 years.

De Materia Medica is justly considered the foundation for all herbal literature. Why was De Materia Medica, in contrast to the botanical works of Theophrastus, so influential? First, as 

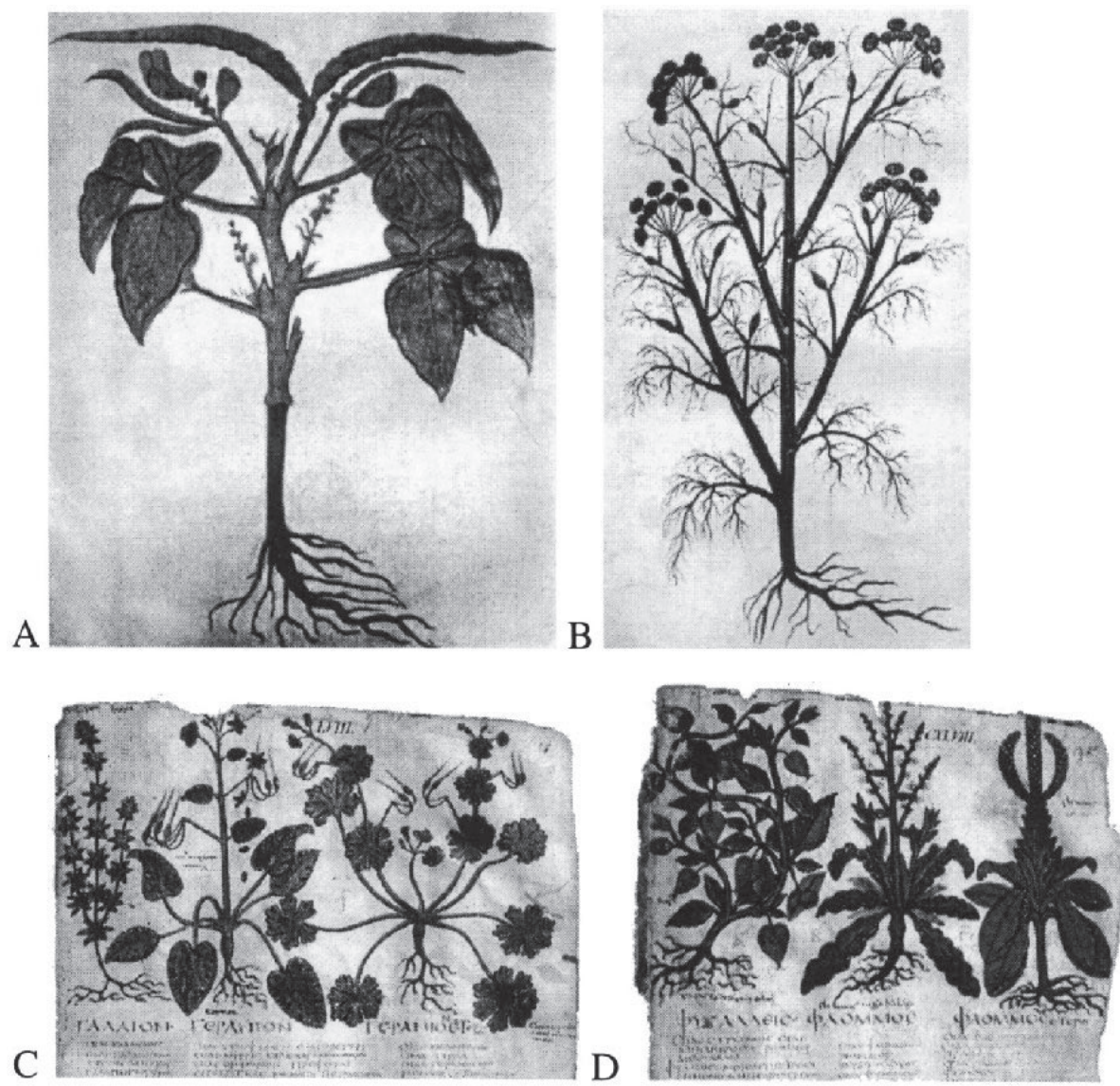

Fig. 6. Images from Dioscorides. (A) Cowpea; (B) Ferula, Codex Vindobonensis, about 512 CE. Source: Arber (1938); (C) Lady's bedstraw (Galium), Cranesbill (Erodium), and Geranium; (D) Winter cherry (Physalis) and Mulleins (Verbascum). Codex Neopolitanus, $7^{\text {th }}$ century. Source: Blunt and Raphael (1979).

indicated by Dioscorides' introductory remarks, it was clearly written as a medical treatise speaking directly to the needs of the patient: "Now it is obvious to everybody that a Treatise on Medicines is necessary for it is conjoined to the whole art of Healing, and by itselfyieldsamighty assistance to every part." Furthermore, it is presented in a straightforward, more practical manner than the earlier botanical treatises by Theophrastus who is more scholarly and scientific, seemingly interested in plants for their own sake. Yet, Dioscorides did make an effort to systematize knowledge with plants, grouping them by form and origin, a practice continued until Linnaeus.

PLINY's Historia Naturalis. Pliny the Elder (23-79), the prolific author of Historia Naturalis, compiled a monumental encyclopedic treatment of science and ignorance. Pliny's coverage of the natural world is the best known and most widely referred source book on classical natural history. Although over credulous, Pliny is an amazing font of information on every conceivable fact and legend including large sections on plant cures and medicinal uses. While most of the herbals of antiquity have perished, we know of them indirectly from the writing of others, particularly Pliny. He records that Krateuas, a Greek herbalist and physician to Mithridates VI, King of Pontus from 120-63 BCE (the hero of an early Mozart opera), described the nature of herbs and painted them in color (Pliny is dismissive of their quality), creating the first illustrated herbal.

Herbal of Apuleius Platonicus. An herbal derived from Pliny and Dioscorides, known as the Herbal of Apuleius Platonicus, may have been originally compiled around $400 \mathrm{CE}$ and is the source of many medieval illustrated herbals. The text is much inferior to Dioscorides and the illustrations are crude but it appears to have gone through many revisions and transformations. The earliest extant manuscript dates from the $6^{\text {th }}$ century and it was translated into
Anglo-Saxon in the $11^{\text {th }}$ century. The Apuleius herbal despite its poor quality was to have a powerful influence in the medieval world.

\section{Medieval herbal manuscripts}

After the fall of the Roman Empire in the $6^{\text {th }}$ century, there was a decline in knowledge in the Western World and a period of regression, known to us as the Dark Ages. During the next 600 years the center of gravity of intellectual thought shifted to the Moslem world, a byproduct of the invasion and conquest of Byzantium. Moslem and Jewish scholars collected manuscripts from antiquity, developed scientific and technological schools of learning, and translated the manuscripts from Greek to Arabic. Vestiges of scholarship persisted in the monastery libraries where learning was kept alive in the West, although the Christian Church was more interested in theology than natural history.

The Physica of Hildegarde of Bingen (1099-1179), was the first book in which a woman discusses plants in relation to medical properties and the earliest book on natural history in Germany. Hildegarde was a mystic, prolific author, and abbess of a Benedictine convent. The Physica, her only scientific work, was to have a great influence on the German botanists of the $16^{\text {th }}$ century (see below).

Albert of Bollstat, 1193-1280 (known as Alberto Magnus or Albert the Great), (Fig. 7) was an early member of the Dominican Order of Preaching Friars that established scholarly houses in the European Centers of Learning. He was responsible for the translations of Aristotle and influenced the revival of botanical and horticultural information based on the writing of antiquity in his work On Plants. Most medieval writers thereafter drew inspiration from the DioscoridianPlinian tradition although the descrip-

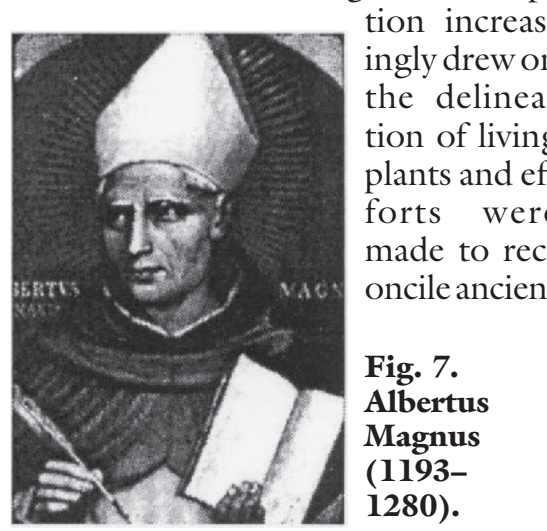





Fig. 8. Medicinal plants based on the Doctrine of Signatures in Porta's Phytognomonica. Source: Anderson (1977). (A) Heart plants include peaches, citrons and bulbous roots. (B) Plants for scaly diseases include pine cones, thistles, catkins, and lily bulbs. The snake and fish were added to show scaly skin. writings with native flora. By the $14^{\text {th }}$ century, a trend toward more naturalistic drawings became apparent suggesting the influence of the Renaissance in art and ideas. Plants were no longer slavishly copied from past manuscripts but redrawn afresh, with artists taking advantage of the local flora.

In the late Middle Ages, the concept of doctrine of signatures developed in which the inner qualities of herbs were thought to be revealed by external signs (Fig. 8). This was codified by mystical writers such as Paracelsus(1493-1541) and Gianbattista Porta, author of Phytognomonica (1588). Thus, long-lived plants would lengthen a man's life, short-lived plants would abbreviate it. Yellow sap would cure jaundice, plants with a rough surface would cure diseases that destroy the smoothness of skin, and plants that resembled butterflies would cure insect bites. The concept was that medicinal plants were stamped with a clear indication of their uses. A $17^{\text {th }}$ century dispensary explains the concept.

The powers of Hypericum are deduced as follows: I have oft declared how by the outward shapes and qualities of things we know their inward virtues which God hath put in them for the good of man. So in John's wort we take notice of the form of the leaves and flowers, the porosity of the leaves, the Veins. 1. The porosity roles in the leaves signifie to us, that his herb helps both inward and outward holes or cuts in the skin. 2. The flowers of Saint John's wort, when they are putrified they are like blood; which teacheth us, that this herb is food for wounds, to close them and fill them up [Paracelus from Arber (1938)].

\section{Printed herbals}

The advent of printing in the $15^{\text {th }}$ century and the technology of the woodblock print was to have a enormous influence in herbals. Printed herbals were in great demand by physicians, the apothecary, as well as the educated elite who needed a source for remedies. Hand-illuminated manuscripts were too expensive to be owned by all except nobility or clergy in wealthy monaster-
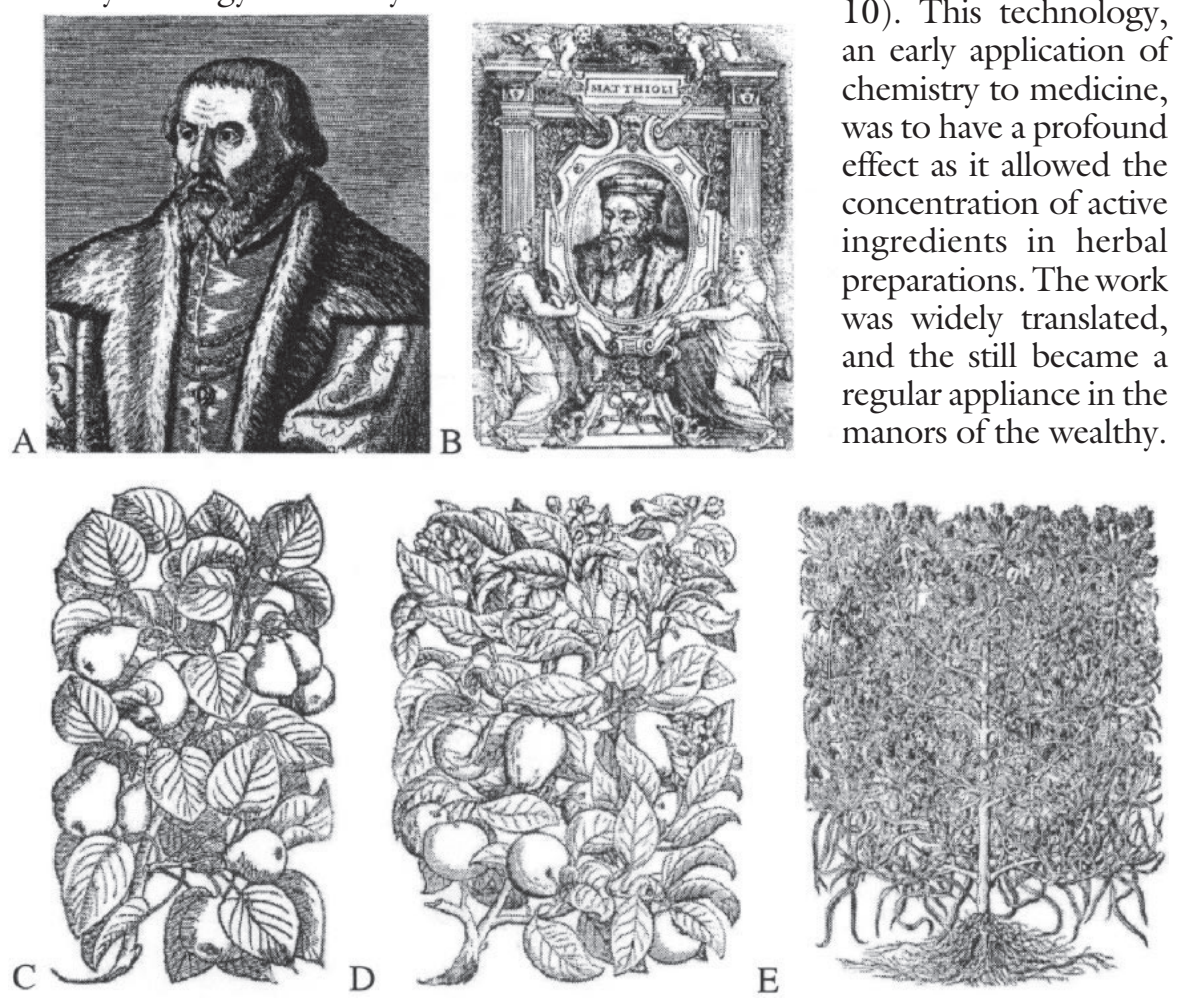

Fig. 9. (A) Pierandrea Mattioli, 1501-1577. Source: Arber (1938). (B) Portrait from the first Bohemian edition of Commentarii (on Dioscorides). The motto nec igne, nec ferro (neither fire nor iron) refers to his preference for medication over surgery. Source: Anderson (1977). (C) Woodblock print of pear. Source: Arber (1938). (D) Woodblock print of apple. Source: Arber (1938). (E) Woodblock print of psyllium. Source: Singer (1958). 


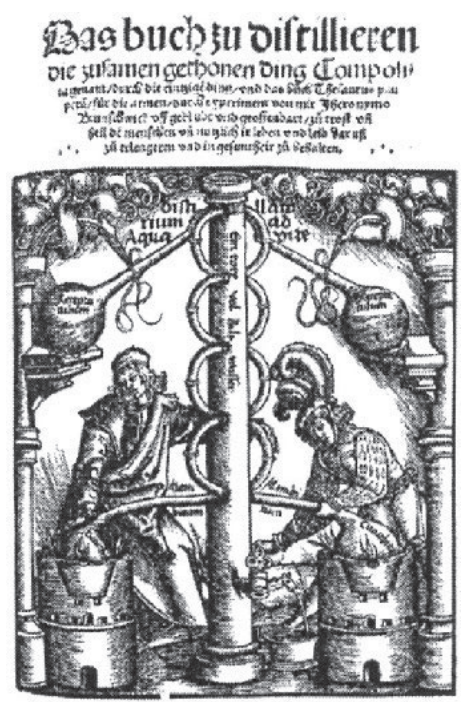

Fig 10. Heironymus Brunschwig's frontpiece for Das Buch $z u$ Distillieven 1500. Source: Anderson (1977).

The German fathers of botany. German Lutherans, who reformed both the church and botany, authored a series of new herbals. These included Otto Brunfels (1468-1534), Jerome Bock (Hieronymous Tragus) (1498-1544), and Leonhart Fuchs (1501-1566).

Otto Brunfels, former theologian and monk, was the author of the influencial Herbarum Vivae Eicones in 1530 (Fig. 11). Its value was based not on the text but on the use of stunning and lifelike woodcuts by Hans Weiditz who drew plants from nature. This breakthrough in the printed herbals made it possible for ordinary people to actually identify the plant from the drawing.

Jerome Bock (Fig. 12) created a well written, nonillustrated herbal called the Kreüter Buch that proved to be more scientific than any since Theophrastus. He perfected a new arrangement of plants and undertook a new direction, a discussion of the characteristics and names of local plants, drawn from his own experience in Germany.

Leonhart Fuchs (Fig. 13) studied at the University of Ingolstadt and received a Master of Arts and Doctor of Medicine. His great work, De Historia Stirpium, was based on Dioscorides but the woodcuts reached a new level of excellence from both a botanical and artistic point of view. Chapter headings were in Greek and plants were labeled in Latin and German. The terms masculine and feminine were used, not in the sexual sense, but to distinguish stronger and weaker qualities in plants, a medieval concept. The 508 woodcuts supervised by Fuchs were outstanding and formed the basis for later herbals. Over 100 new plants are mentioned including maize, called Türkisch korn because it was thought to come from Turkey rather than the Americas. The same error was responsible for the misnomer of the American bird we still call turkey!

The Flemish вотAnists. Three Flemish botanists, Rembert Dodoens, Charles de l'Escluse, and Matthias de l'Obel, have been immortalized with genera names in their honor: Dodoneae, Clusia, and Lobelia. Dodoens, 15171585 (Fig. 14), the most prominent, was born in Flanders and graduated in medicine from the University of Louvain at the age of 18 years. He later became the personal physician of the Emperor Maximilian II, and later Rudolph, but ultimately finished his career at the University of Leyden as Chair of Medicine (1582). His major botanical work, Crôÿdeboeck published in 1554, provided the basis for all further botanical writings and was eventually published as Stirpium Historiae in Pemptades Sex, a folio volume of 900 pages with 1,309 woodcuts, many of them copied from Fuchs and six of them from the Codex Vindobonensis of Dioscorides. Charles de l'Ecluse (Charles de l'Escluse or Carolus Clausius) translated the Crôÿdeboeck
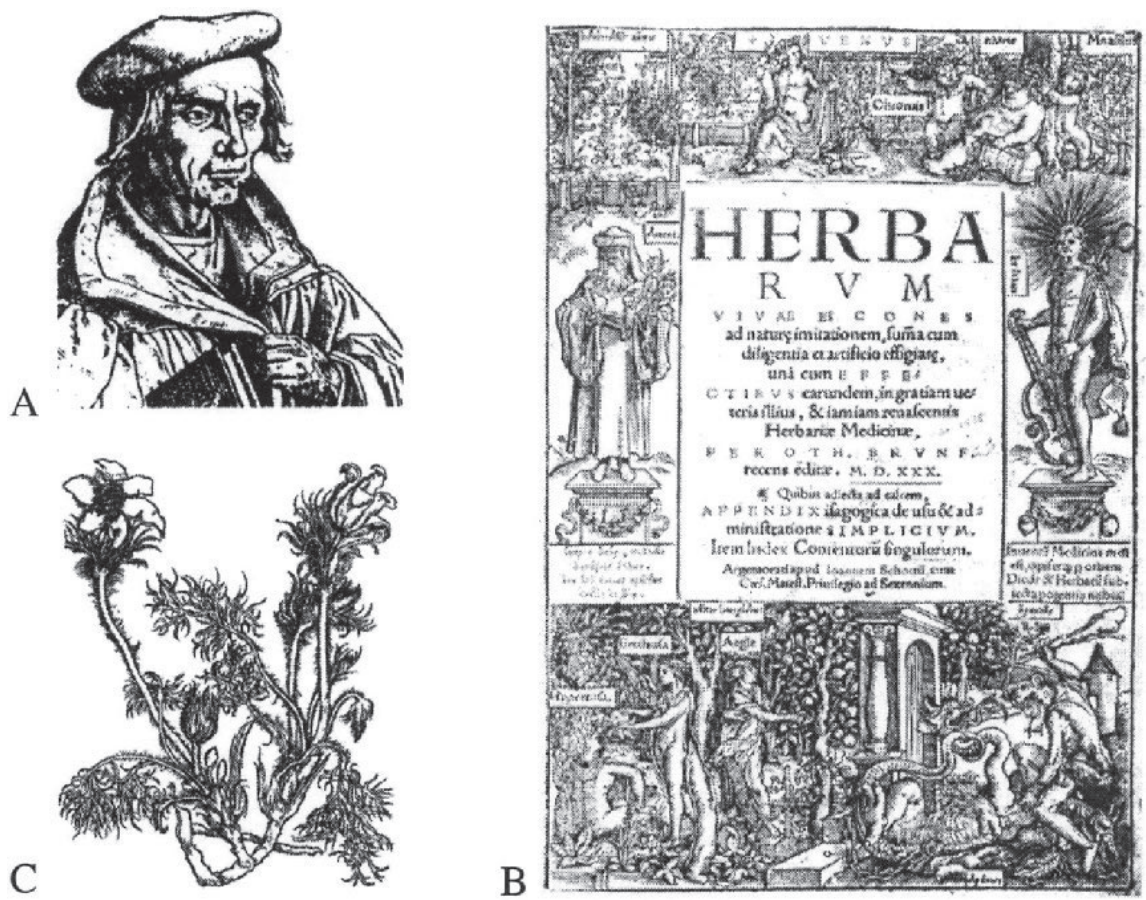

Fig. 11. (A) Otto Brunfels. (B) Herbarium Vivae Eicones frontpiece, 1530. (C) Image of Anemone pulsatilla, showing the advance in drawing. into French under the title Histoire des Plantes (Fig. 15). Matthias de l'Obel (died 1616) spent much of his professional life in England (Fig. 16). He coauthored a work, Stirpium Adversaria Nova with Pierre Pena, with an improved system of classification, and was an ill-fated colleague of John Gerard (see below).

English herbals. The herbal in English has a tortuous history (Henrey, 1975). There were some manuscripts as early as the $6^{\text {th }}$ century and a 10th century fragment, Leech Book of Bald (900-950), is the oldest to survive. After the Norman conquest, Anglo Saxon herbals fell into disrepute and Latin took over as the language of the educated but many English herbals were merely translations. The new herbals were delayed in England because printing had a late start.

Banckes' Herbal of 1524 was the first printed English Herbal and went through many editions and emendations. A compilation by Richard Banckes rather than a translation, it was probably based on a medieval manuscript. The first illustrated English herbal was the Grete Herball of 1527 (Fig. 16), a translation from the French (Le Grant Herbier) with parts derived from German herbals [Herbarius (1485) and the Hortus Sanitatus (1491)].

William Turner (1508-1568), known as the Father of British Botany, 


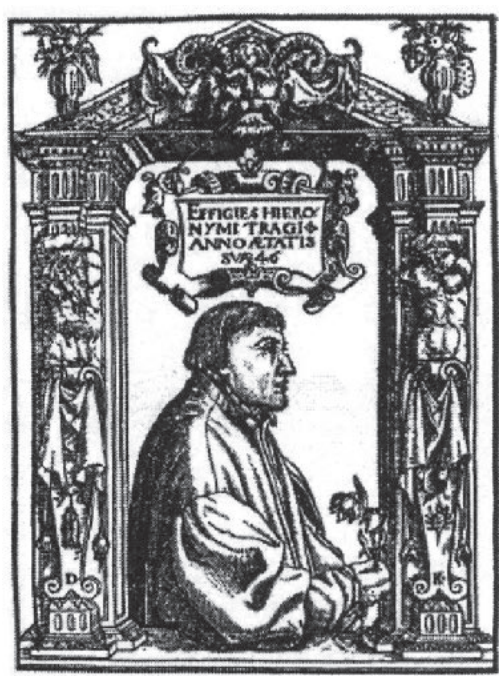

Fig. 12. Hieronymus Bock or Tragus 1498-1554. Author of Kreuter Buch, 1551. Source: Arber (1938).

published two small books in 1583 , giving the names of herbs in Greek, Latin, English, German, and French. His famous Herball published in three parts (1551, 1562, and 1568) was the first to describe British plants from observation and experience. Over 200 species native to England are described. He scoffed at superstitions and cautioned against overuse of any herb. In 1578, Henry Lyte (1529-1560) produced $A$ Nievve Herball, an English translation of l'Ecluse's French version of Dodoen's Crôÿdeboeck of 1554 (Fig. 18).

The most famous English herbal, and deservedly so, is The Herball or Generall Historie of Plantes by John Gerard (1545-1612) known as Gerarde's Herball of 1597 . John Gerard, the best known of English herbalists, was a barber-surgeon by profession, but enamored of horticulture. He had a famous garden at Holborn (Fetter's Lane) and supervised the garden of William Cecil (Lord Burleigh), the famous minister of Queen Elizabeth, in the Strand and at Theobalds in Herfordshire. In 1596, he compiled a list of plants at Holborn, the first catalogue ever published in England from which it is possible to benchmark the introduction of new plants to England.

The origins of the work are fascinating. The printer John Norton commissioned a certain Robert Priest to translate Dodoens final work, the Pemptades of 1583, but Priest died before completion. Gerard adopted
Priest's translation but changed the arrangement from Dodoen to that of l'Obel. In his introduction he writes: "...Doctor Priest, one of our London Colledge, hath (as I heard) translated the last Editions of Dodonaeus, and meant to publish the same; but being prevented by death his translation likewise perished." According to Arber (1938) the interpolation "as I heard" is undoubtedly a falsehood. One of the prefatory letters written by Stephen Bredwel acknowledges: “D. Priest for his translation of so much as Dodonaeus hath hereby left a tomb for his honorable sepulture. M. Gerard coming last but not the least, hath many waies accommodated the whole worke into our English nation..." (Moral: Read your prefatory letters!).

The wood blocks in the Gerard herbal are from the Eicones Plantarum of Jacobus Theodorus (Tabernaemontanus) of 1590 . There were some problems in getting the right woodcuts with the correct description and l'Obel was requested to correct the figures.
An argument developed and Gerard stopped the collaboration on the shaky grounds that l'Obel had forgotten his English!

Although Gerard is somewhat credulous and his reputation is tarnished, his style is graceful and Elizabethan. It is his additions that give the work its charm and character. The Herball is famous for the first English description of sweet potato and potato. The first edition held the field without competition for a generation when it was rumored that a John Parkinson would soon produce a new herbal. Thus, Thomas Johnson was commissioned to prepare a new edition of Gerard's Herball. The second edition of 1633 contained 2766 wood blocks and is considered superior to the original. Dover Press printed a facsimile edition in 1975 (Fig. 19).

Nicholas Culpeper (1616-1654), the author of A Physicall Directory, was an herbalist who abandoned common sense, and the leading $17^{\text {th }}$ century exponent of astrological botany

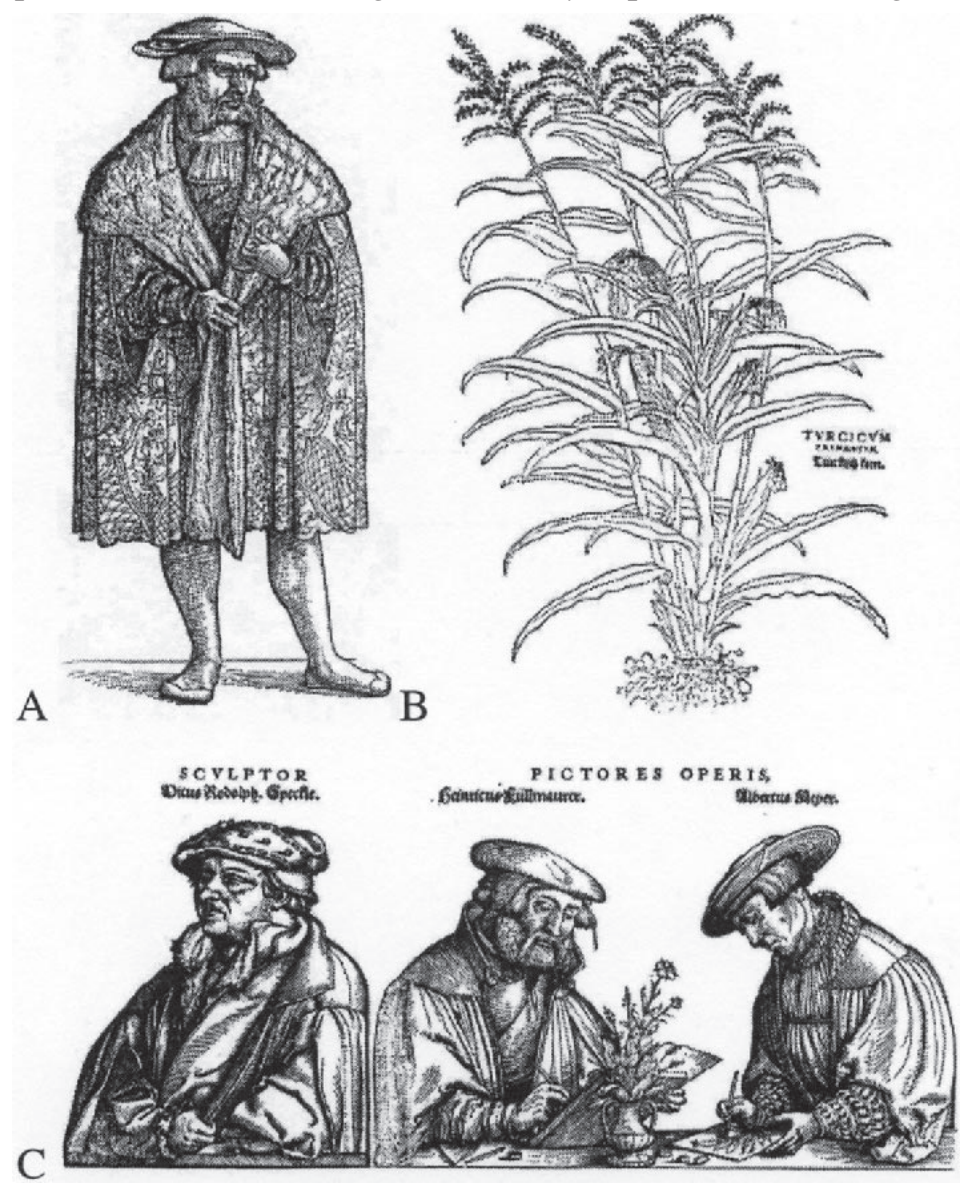

Fig. 13. (A) Leonhard Fuchs (1501-1566). Source: Arber (1938). (B) The first woodcut of maize called Türckisch korn from De Historia Stirpium 1542. Source: Blunt and Raphael (1979). (C) Engraver (Veit Rudolf Speckle) and illustrators (Heinrich Fullmaurer and Albrecht Meyer) of De Historia Stirpium. Source: Arber (1938). 

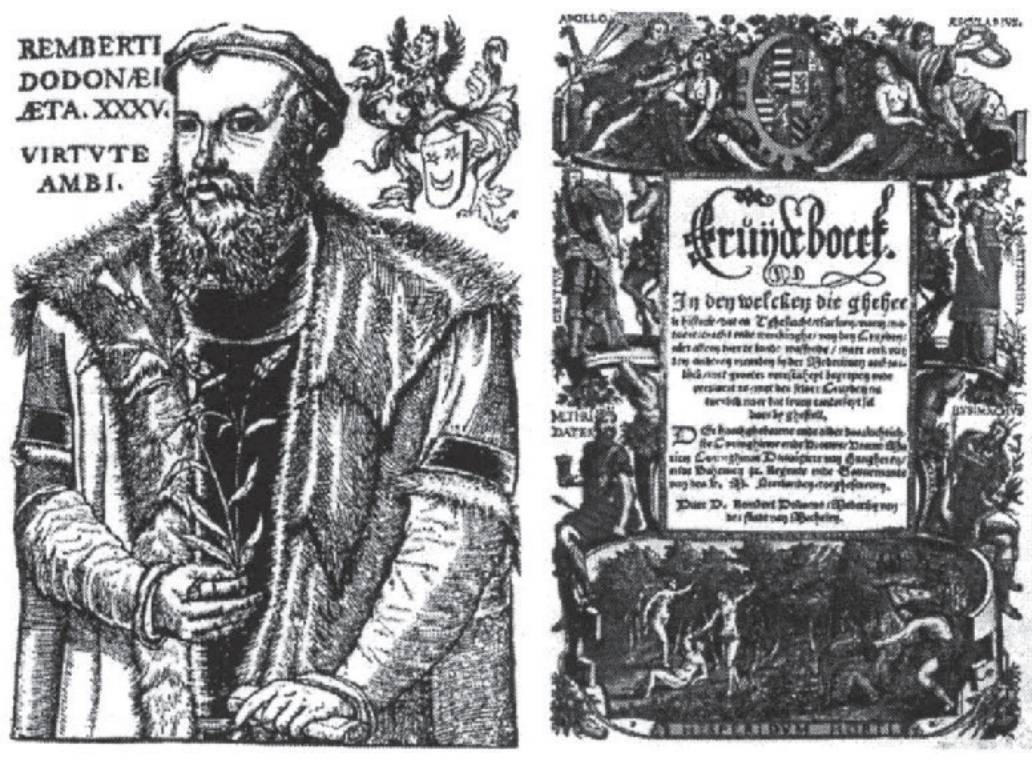

Fig. 14. Rembert Dodoens, 1517-1585. Source: Arber (1938).

Frontpiece of Crôyjdeboeck, 1554. The French translation was published in English, 1578, under the title of A Nievve Herbal by Henry Lyte. 1578 (see Fig. 17).

(Fig. 20). He believed that every disease was caused by a planet and that in order to effect a cure an herb belonging to an opposing planet must be used. He also held the view that cures could sometimes be made by sympathy, this is by the use of herbs under the dominion of the planet responsible for the disease, "every planet cures his own disease" he wrote "as the sun and moon by their herbs cure the eyes, Saturn the spleen, Jupiter the liver, Mars the gall, and diseases of choller" (Henrey, 1975). Culpepper was immensely popular up to the $19^{\text {th }}$ century and is still quoted by the credulous.

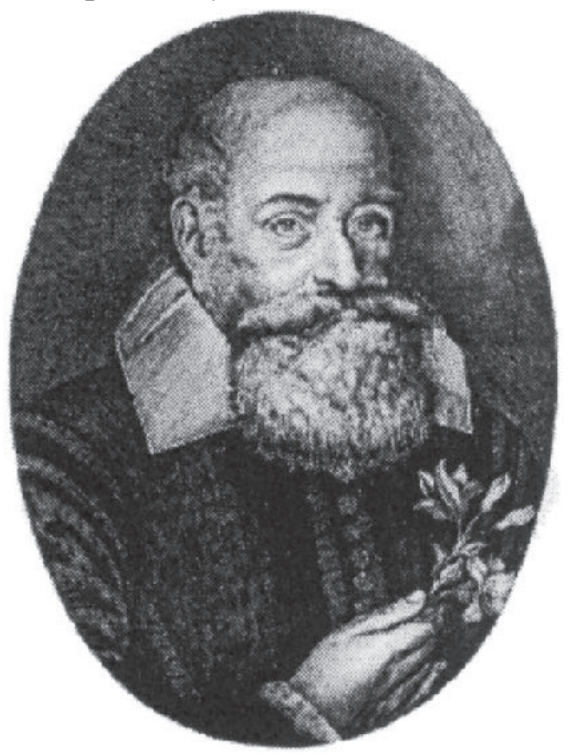

Fig. 16. Mathias de L'Obel (15381616). Source: Arber (1938).

\section{Conclusions}

Herbal cures in the past vary from sensible, ineffective, ridiculous, to harmful. While we smile at the outrageous claims of the herbalist, it is a fact that drugs derived from plants still remain the basis for much of modern medicine. The modern trend is to discover the active ingredient and synthesize variations or permutations of the efficacious molecules. Unfortunately pharmaceutical companies are not interested in botanicals as such because they cannot be protected by patent. The recent interest in herbs as cures or inducers of wellness is now a prominent part of alternate medicine and has

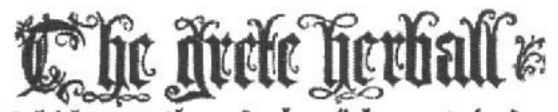

Iobídje getucthparive knolblegeano bnoet

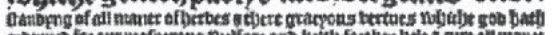

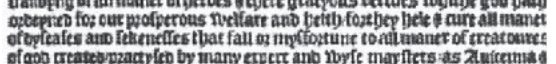

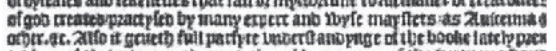

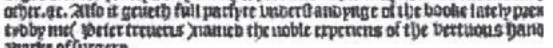
zoarte of furgere.

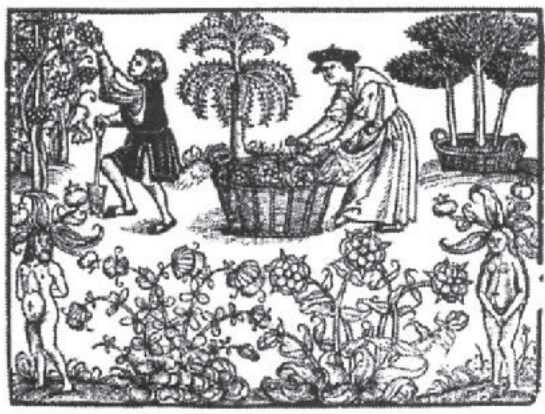

Fig. 17. The Grete Herball of 1526. Source: Henrey (1975). led to a revival of interest in the old herbals. Some of the ancient herbs have been resurrected, and in many cases new benefits have been claimed. These include echinacea, approved in Germany for supportive therapy for colds and chronic infections of the respiratory tract and lower urinary tract, ginseng as a tonic and adaptogen, and St. John's wort for mild depression. The reader is advised to be cautious and pursue a common sense approach to herbal medicine. An authoritative review of herbal medicine can be found in The Honest Herbal: A Sensible Guide to Herbs and Related Remedies by Varro E. Tyler (1981).

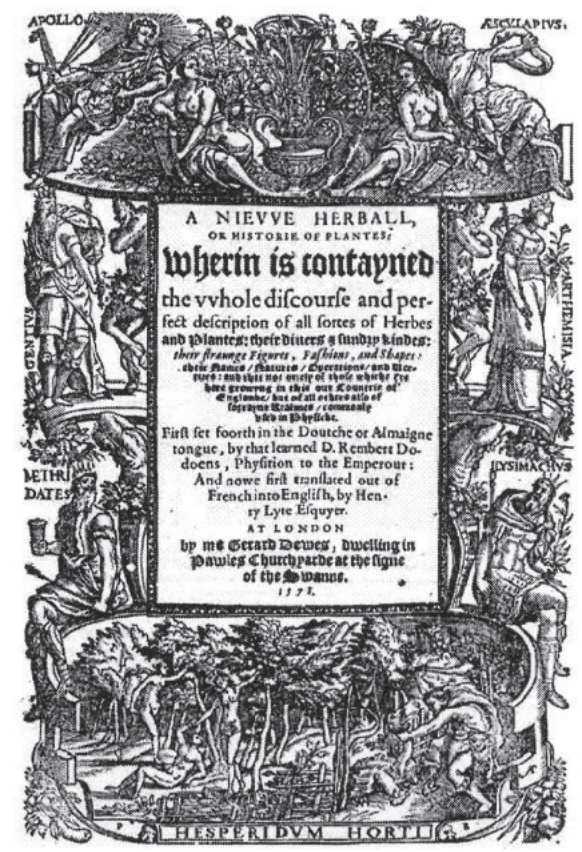

Fig. 18. Lyte's A Nievve Herball of 1578. Source: Henrey (1975). 


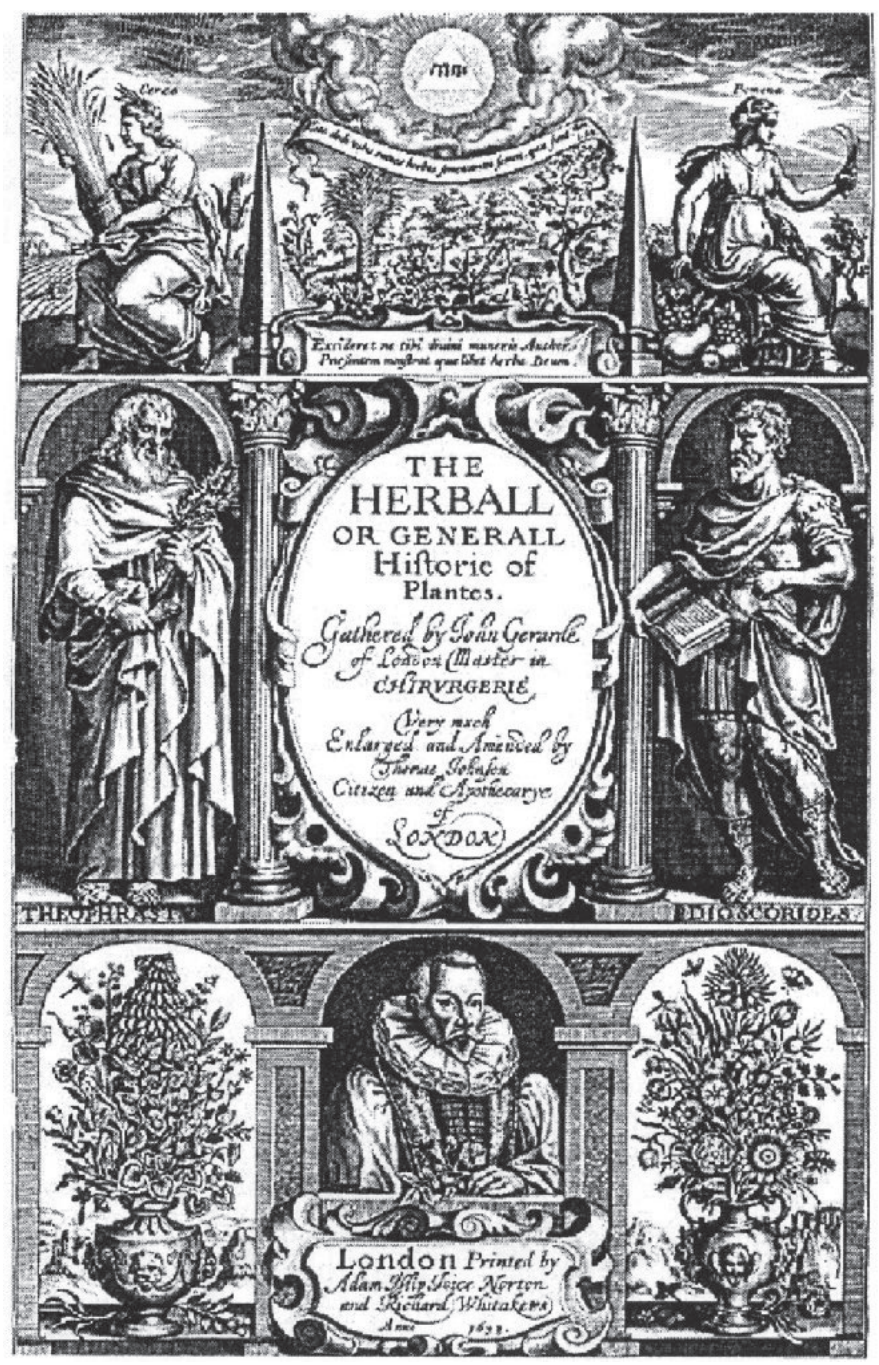

Fig. 19. Frontpiece of The Herball of Jobn Gevarde, $2^{\text {nd }}$ ed. (1633).

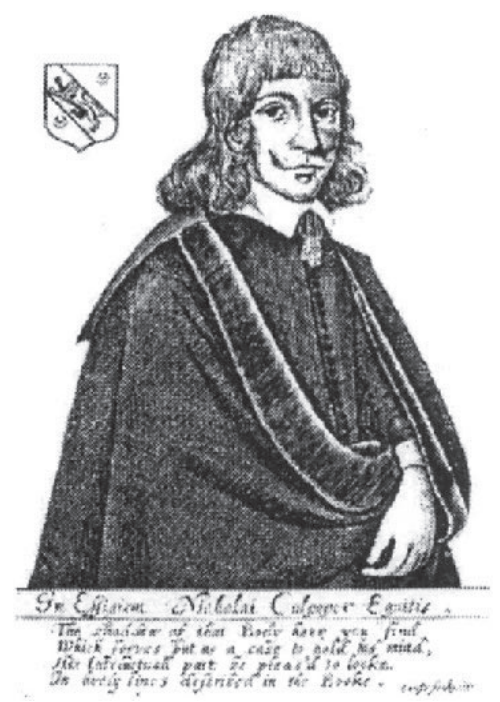

Fig. 20. Nicholas Culpeper (16161654), astrologic botanist. Source: Arber (1938).

\section{Literature cited}

Anderson, F.J. 1977. The illustrated history of the herbal. Columbia Univ. Press, New York.

Arber, A. 1938. Herbals: Their origin and evolution; a chapter in the history of botany. $3^{\text {rd }}$ ed. Cambridge Univ. Press, Cambridge.

Blunt, W. and S. Raphael. 1980. The illustrated herbal. Thames and Hudson, New York.

Bryan, C.P. 1936. The papyrus Ebers. D. Appleton and Co., New York.

Christopher, T.A. 1981. The seeds of botany. Natural History 9(3):50-56.

Cowen, D.L. and W.H. Helfand. 1988. Pharmacy: An illustrated history. Harry N. Abrams, Inc, New York.

D'Andrea, J. 1982. Ancient herbs. J. Paul Getty Museum, Malibu, Calif.

Gerard, J. 1633. The herball or general historie of plants very much enlarged and amended by Thomas Jefferson. Adam Islip, John Norton and Richard Whitaker, London (Dover facsimile ed., 1925).

Gunther, R.T. 1934. The Greek herbal of Dioscorides. Oxford Univ. Press, Oxford.

Henrey, B. 1975. British botanical and horticultural literature before 1800. 3 vol. Oxford Univ. Press, Oxford.

Janick, J. 1989. Theophrastus, p. 3-13. In: J. Janick (ed.). Classical papers in horticultural science. Prentice Hall, Englewood Cliffs, N.J.

Janick, J. 2002. Ancient Egyptian agriculture and the origins of horticulture. Acta Hort. 582:23-39.

Kramer, S.N. 1954. First pharmacopeia in man's recorded history. Amer. J. Pharmacy 126:76-84.

Rosengarten, Jr., F. 1969. The book of spices. Jove. Publ., New York.

Singer, C. 1923. Herbals. Edinburgh Rev. 237:85-112.

Singer, C. 1927. The herbal in antiquity and its transmission to later ages. J. Hellenic Studies 47:1-42.

Singer, C. 1958. From magic to science. Dover, New York.

Sonnedecker, G. 1976. Kremers and Urdang's history of pharmacy $4^{\text {th }} \mathrm{ed}$. Lippincott, Philadelphia.

Tyler, V.E. 1981. The honest herbal. George F. Stickley Co., Philadelphia. 